\title{
Rola etylenu i zmiany na poziomie transkryptomu w odpowiedzi na stres niedotlenienia u roślin
}

\section{mgr Sylwia Górka ${ }^{\varpi}$, \\ lic. Dorota Olszewska, \\ lic. Dawid Kubiak, \\ dr hab. Janusz Niedojadło, prof. UMK ${ }^{\varpi}$}

Katedra Biologii Komórkowej i Molekularnej, Uniwersytet Mikołaja Kopernika w Toruniu

https://doi.org/10.18388/pb.2020_307

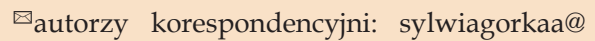
gmail.com (SG); janiaszn@umk.pl (JN)

Słowa kluczowe: stres niedotlenienia (hipoksja), ERF - czynniki odpowiedzi na etylen, transkryptom, Ribo-seq, retencja RNA w jądrze komórkowym

Wykaz skrótów: ADH1 - (ang. alcohol dehydrogenase 1) - dehydrogenaza alkoholowa; ERF (ang. ethylen respose factor) - czynnik odpowiedzi na etylen ERF; ET - (ang. ethylene) - etylen; GABA - (ang. gamma aminobutyric acid) - kwas gamma aminomasłowy; HRE - (ang. hypoxia responsive ERF) - gen odpowiedzi na hipoksję; Ribo-seq - (ang. ribosome profiling) - profilowanie rybosomów; ROS - (ang. reactive oxygen species) - reaktywne formy tlenu; TCP4 - (ang. TEOSINTE BRANCHED/CYCLOIDEA/PROLIFERATING CELL FACTORS) - negatywny czynnik proliferacji komórki

Podziękowania: Badania prowadzone przez autorów niniejszej pracy przeglądowej finansowane są ze środków na naukę przyznanych przez Narodowe Centrum Nauki na realizacje projektu badawczego OPUS11: 2016/21/B/ NZ3/00367 (2017-2020)

\section{STRESZCZENIE}

Tiedotlenienie (hipoksja) u roślin jest zazwyczaj wynikiem intensywnych opadów desz1 czu i następujących po nich powodzi. Obecne modele klimatyczne wskazują na znaczny wzrost tych zjawisk w najbliższym latach. W zależności od gatunku i miejsca występowania, rośliny podczas ewolucji wykształciły dwie strategie adaptacyjne do stresu hipoksji: ucieczki i uśpienia. Pierwsza z nich polega na jak najszybszym wynurzeniu przynajmniej części pędu nadziemnego nad poziom wody, natomiast druga na silnym obniżeniu tempa metabolizmu w celu przeczekania niekorzystnych warunków środowiska. Procesy te są regulowane głównie przez etylen oraz czynniki transkrypcyjne ERF (ang. ethylen response factor), które aktywują geny odpowiedzi na niedotlenienie. Większość genów ERF ulega konstytutywnej ekspresji niezależnie od stężenia tlenu. Jednak potranslacyjne modyfikacje N-końca ERF prowadzą do ich degradacji u roślin rosnących w warunkach fizjologicznych. Podczas niedotlenienia następuje wzrost poziomu ekspresji genów związanych z metabolizmem węgla, azotu, glikolizą czy oddychaniem beztlenowym. Jednak jak wykazały badania z zastosowaniem profilowania rybosomów, w celu oszczędzania energii, rośliny poddane stresowi hipoksji silnie hamują proces inicjacji translacji. Na regulację ekspresji genów w warunkach stresowych ma wpływ także kumulacja poliadenylowanych RNA w jądrze komórkowym i w cytoplazmatycznych granulach stresowych.

\section{WSTĘP}

Hipoksja, inaczej niedotlenienie jest konsekwencją zmian zachodzących $\mathrm{w}$ środowisku, w którym wzrastają rośliny. Częste deszcze, powodzie, gruba warstwa śniegu oraz okresowe zalewanie terenów powodują deficyt tlenowy. Wynika to $\mathrm{z}$ utrudnionej dyfuzji oraz słabej rozpuszczalności tlenu w wodzie przez co jego dostępność dla roślin jest utrudniona. Na podstawie poziomu wody na obszarze wzrostu roślin, można wyróżnić dwa typy powodzi: (i) silne zawilgocenie gleby skutkujące zalewaniem korzeni (ang. waterlogging) oraz (ii) zalanie całego siedliska, gdy woda całkowicie pokrywa także nadziemne pędy roślin (ang. submergence) [1]. Oba rodzaje powodzi zakłócają przepływ tlenu z powietrza do tkanek roślin generując niedotlenienie (poziom tlenu $<21 \% \mathrm{O}_{2}$ ) $[1,2]$. Powoduje to przede wszystkim wzrost procesu glikolizy i obniżenie syntezy ATP, a także rozrost ryzosfery. Zwiększona aktywność mikroorganizmów w glebie, które wykorzystują azotany, tlenki manganu, żelaza i siarki jako alternatywne akceptory elektronów sprzyja zwiększeniu stężenia $\mathrm{N}_{2} \mathrm{O}, \mathrm{Fe}^{2+}, \mathrm{Mn}^{2+} \mathrm{w}$ podmokłej glebie. Wysokie stężenie rozpuszczalnych jonów $\mathrm{Fe}^{2+}, \mathrm{Mn}^{2+}$ staje się toksyczne i negatywnie wpływa na wzrost i rozwój rośliny [3,4]. Jeśli zalanie utrzymuje się przez dłuższy okres, następuje zaburzenie metabolizmu, w tym przejście na oddychanie beztlenowe prowadzące do kryzysu energetycznego [4]. Towarzyszy temu szybka kumulacja etylenu oraz reaktywnych form tlenu (ROS, ang. reactive oxygen species) i tlenku azotu w roślinie [5]. Zatopienie całych roślin zmniejsza także ich dostęp do światła słonecznego oraz ogranicza dostępność dwutlenku węgla [6].

Deficyt tlenowy wywołany stanami powodziowymi jest ważnym czynnikiem decydującym o składzie gatunkowym ekosystemu. Dodatkowo, hipoksja na gruntach uprawnych prowadzi do szkód ekonomicznych, wywołujących także długofalowe konsekwencje społeczne, zwłaszcza w państwach słabo rozwiniętych ekonomicznie. W latach 2006-2016 powodzie były przyczyną dwóch trzecich wszystkich szkód i strat w uprawach o łącznej wartości 96 miliardów dolarów (Organizacja Narodów Zjednoczonych ds. Wyżywienia i Rolnictwa [FAO], 2017). Największe straty finansowe odniesione na skutek ekstremalnych deszczy monsunowych odnotowano w latach 2010-2014 w Pakistanie. Powodzie na tym obszarze doprowadziły do utraty 11 miliardów ton plonów, w tym ryżu, trzciny cukrowej, kukurydzy i bawełny, co w przeliczeniu na straty ekonomiczne stanowiło około 16 miliardów dolarów [7]. W ostatnich latach na globalne rolnictwo poważnie wpłynęły także powodzie w Europie. W roku 2014 w Bośni i Hercegowinie straty z powodu zalania upraw rolnych wyniosły 255 milionów 
dolarów. Dodatkowe koszty były spowodowane opóźnieniem sadzenia roślin z powodu ograniczonego dostępu do gruntów ornych (Organizacja Narodów Zjednoczonych ds. Wyżywienia i Rolnictwa [FAO], 2017).

$\mathrm{Na}$ podstawie 11 modeli klimatycznych oszacowano ryzyko wystąpienia powodzi do końca tego stulecia. Prognozowany jest wzrost częstotliwości powodzi na obszarze południowo - wschodniej Azji, Półwyspu Indyjskiego, wschodniej Afryce oraz północnej części Andów. Na skutek podniesienia poziomu wody w oceanach zalaniu będą także podlegać wybrzeża Europy. Badania wskazują, że ryzyko wystąpienia powodzi będzie wyższe wraz ze wzrostem temperatury na skutek globalnego ocieplenia [8].

\section{STRATEGIA UCIECZKI I SPOCZYNKU}

Pomimo, że podczas powodzi ilość tlenu, czy regulującego odpowiedź na stres etylenu jest podobna u wszystkich roślin, wyzwala to różne strategie odpowiedzi na nadmiar wody. Najczęściej jest to cecha gatunkowa u roślin polegająca na odmiennych kaskadach sygnalizacji. Wyróżniamy dwie główne strategie: (i) ucieczki ze środowiska niskiego poziomu tlenu - LOES (ang. Low - $\mathrm{O}_{2}$ Escape Syndrome) i (ii) spoczynku, polegająca na przeczekaniu niekorzystnych warunków - LOQS (ang. Low - O Quiescence Syndrome) [8].

Strategia ucieczki polega na jak najszybszym wynurzeniu przynajmniej części pędu nadziemnego nad poziom wody. Następuje to głównie przez wzrost w międzywęźlach, czy wydłużenie ogonków liściowych. Sprzyja temu zwiększenie ilości wytwarzanych korzeni bocznych oraz zmiana anatomii liści [5]. Powstaje aerenchyma, czyli tkanka powietrzna charakteryzująca się dużymi przestworami międzykomórkowymi wypełnionymi powietrzem. Aerenchyma występuje także w korzeniach przybyszowych wyrastających z łodygi lub hipokotylu ułatwiając dyfuzję gazów między korzeniami a nadziemnymi organami roślin [9]. Procesy te wymagają natychmiastowego uruchomienia rezerw magazynowanych węglowodanów.

W strategii ucieczki spotykane są również takie adaptacje morfologiczne jak: redukcja wielkości aparatów szparkowych, wzrost hiponastyczny (szybszy wzrost dolnej warstwy liści lub płatków kwiatu) oraz epinastyczny (szybszy wzrost górnej warstwy liści lub płatków kwiatu). Ten ostatni jest związany z wygięciem w dół ogonków liściowych i jest charakterystyczny dla roślin, które są wrażliwe na stres hipoksji, jak na przykład pomidor zwyczajny (Lycopersicon esculentum), dąb szypułkowy (Quercus robur) oraz dąb bezszypułkowy (Quercus petraea) [4]. W przypadku rzodkiewnika pospolitego (Arabidopsis thaliana) [10] zamknięcie szparek hamuje nadmierną transpirację, dzięki czemu utrzymywany jest potencjał wody w liściach, co opóźnia starzenie i chlorozę liści. Z kolei u szczawiu błotnego (Rumex palustris) występuje hiponastyczność oraz wydłużanie ogonków liściowych, dzięki czemu jest możliwe wynurzenie organu ponad poziom wody i przywrócenie wymiany gazowej. $W$ celu ułatwienia dyfuzji gazów w roślinach, które uległy zalaniu, na hydrofobowej powierzchni liścia tworzy się warstwa gazu umożliwiająca bardziej wydajną wymianę tlenu i dwutlenku węgla między liśćmi a otaczającą je wodą [11].
W korzeniach ryżu, jedną z odpowiedzi na hipoksję jest rozrost egzodermy graniczącej z korą, która ma zapobiec nadmiernej utracie tlenu. Dodatkowo chroni to roślinę przed fitotoksynami wytwarzanymi przez mikroorganizmy, występującymi w środowisku otaczającym korzenie [4,12].

Strategia spoczynku jest drugim mechanizmem przystosowania roślin do stresu hipoksji. Charakterystyczne dla tego zjawiska jest silne obniżenie tempa metabolizmu. W przeciwieństwie do strategii ucieczki nie następuje szybkie uruchomienie zasobów węglowodanów. Minimalne i bardzo powolne korzystanie z substancji zapasowych pozwala roślinie znacznie dłużej przetrwać niekorzystny czas zalania [8]. Jak wykazano na korzeniach łubinu (Lupinus luteus), w strategii spoczynku obniża się istotnie aktywność transkrypcyjna komórek [13]. Dodatkowo nie zachodzą również procesy replikacji, zahamowane są podziały komórkowe, synteza rybosomów i ściany komórkowej [2,14]. U A. thaliana po 9 godzinach hipoksji wykazano także obniżenie translacji o 73\% [15]. Z powodu braku dostępu tlenu, rośliny przeprowadzają proces fermentacji w celu uzyskania energii [8].

Jak wspomniano powyżej mechanizm odpowiedzi na hipoksję jest cechą gatunkową, którą rośliny nabyły w drodze ewolucji wskutek ciągłego dostosowywania metabolizmu do warunków siedliskowych. Dlatego też wymuszona eksperymentalnie zamiana odpowiedzi na deficyt tlenowy nie przynosi oczekiwanych efektów. Rzepicha ziemnowodna (Rorippa amphibia) i rzepicha leśna (Rorippa sylvestris) są roślinami, które występują na terenach zalewowych. Pierwsza z wymienionych roślin rośnie na terenach o płytkich ale dłużej występujących powodziach i dlatego stosuje strategię ucieczki. Natomiast, druga z roślin występuje na terenach, gdzie są głębokie stany wody i dlatego roślina obniża swój metabolizm w celu przetrwania. Wykazano, że jeśli nawet podczas zalania część liści $R$. sylvestris ma kontakt z powietrzem, to przynosi to znacznie mniejsze korzyści niż u R. amphibia. Roślina taka ma niższy przyrost biomasy i po usunięciu warunków hipoksji wolniej obniża ekspresję genu ADH1 (ang. alcohol dehydrogenase 1), który jest jednym z głównych genów biorących udział w odpowiedzi na stres niedotlenienia. Wykazano, że jest to związane z niskim poziomem porowatości ogonków liściowych u $R$. sylvestris $\mathrm{w}$ porównaniu z R. amphibia, a tym samym niższą efektywnością wykorzystania kontaktu organów rośliny z powietrzem [16].

\section{CZYNNIKI ODPOWIEDZI NA ETYLEN ERF (ANG. ETHYLEN RESPOSE FACTOR )}

Podczas powodzi w tkankach gromadzi się etylen (ET, ang. ethylene), który nie może dyfundować z rośliny ze względu na niską rozpuszczalność w wodzie i aktywuje kaskadę sygnalizacyjną zwiększającą tolerancję u roślin. Informacje dotyczące zwiększenia syntezy etylenu podczas hipoksji są niejednoznaczne. Pomimo wzrostu ilości mRNA ACS i ACO enzymów zaangażowanych w biosyntezę ET nie wykazano wzrostu ilości samego ET. Jednym z powodów braku wzmożonej syntezy ET może być zależny od tlenu ostatni etap przekształcenia prekursora ACC do etylenu [17]. W tym kontekście interesujące wydają się doniesienia 


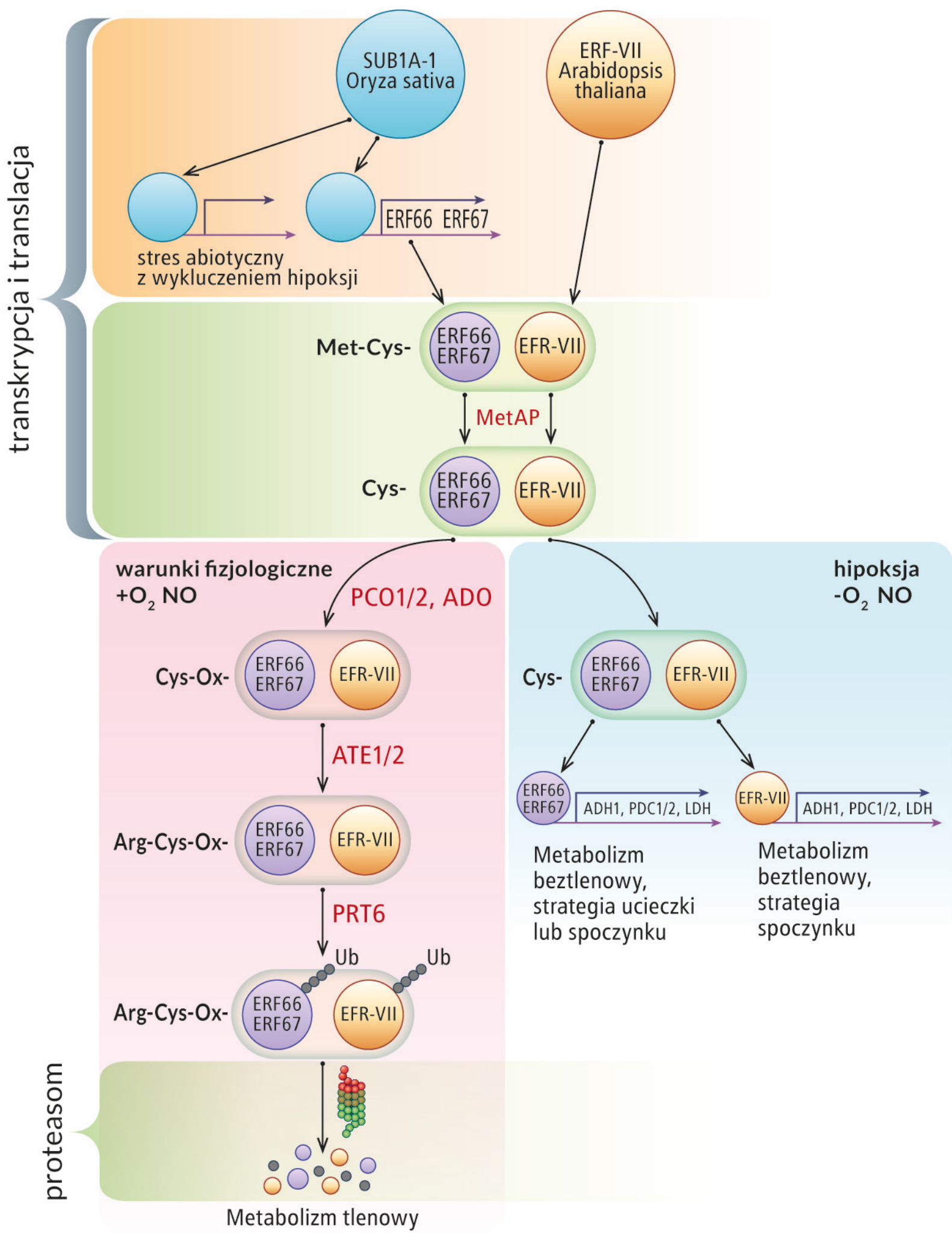

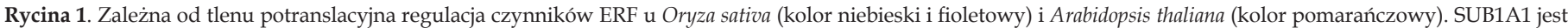

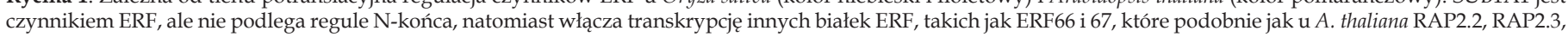

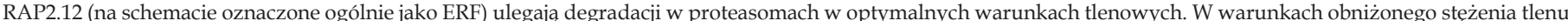

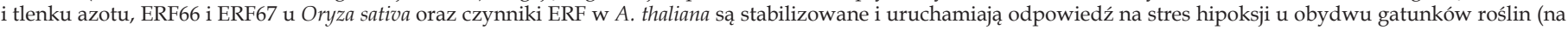
podstawie Bailey-Serres i wsp. [5] oraz Lin i wsp. [30].

wskazujące na funkcje samego ACC w podziałach komórkowych, strukturze ściany komórkowej czy rozwoju zarodków [18]. Receptory ET występujące w błonie retikulum endoplazmatycznego są ujemnymi regulatorami sygnalizacji. Ich unieczynnienie następuje po związaniu ET z jonami miedzi, a następnie z N-końcem receptora. Powoduje 
to blokadę fosforylacji innego białka transbłonowego EIN2 (ang. ethylene insensitive protein 2). W kolejnym etapie sygnalizacji następuje odcięcie C-końca białka EIN2, który w warunkach hipoksji przemieszcza się do jądra komórkowego [12]. Skutkuje to stabilizacją czynników transkrypcyjnych EIN3 i EIN3-like w jądrze komórkowym, które przy bra$\mathrm{ku}$ etylenu są degradowane $\mathrm{w}$ proteasomie przez EBF1/2. Następnie EIN3 i EIN3-like indukują transkrypcję genów ERF-VII (ang. ethylen respose factor). Czynniki ERF posiadają domenę Apetala2 (AP2) wiążącą się do DNA i stanowią jedną z największych rodzin czynników transkrypcyjnych u roślin [19]. U O. sativa występuje 139 czynników ERF, klasyfikowanych na podstawie podobieństw domeny AP2 w 15 podgrupach, a u A.thaliana 122 w 12 podgrupach. Podgrupa VII ERF obejmuje czynniki mające szczególny wpływ na wzrost, rozwój i reakcje roślin na stres hipoksji $[20,21]$. Co ciekawe, geny typu AP2 prawdopodobnie zostały przeniesione $\mathrm{w}$ toku ewolucji $\mathrm{z}$ organizmów prokariotycznych, co potwierdza m. in. brak sekwencji intronowych [20,]. Analiza filogenetyczna genów czynników ERF-VII u 16 gatunków roślin okrytozalążkowych wykazała, że pochodzą one od dwóch przodków. Późniejsza ich duplikacja spowodowała ostatecznie pojawienie się pięciu odrębnych genów. U A.thaliana z 5 głównych genów ERF zaangażowanych w regulację hipoksji, HRE1, RAP2.2, i RAP2.12 mają wspólne pochodzenie synteniczne, a kolejne dwa, HRE2 i RAP2.1, wyewoluowały z drugiego pierwotnego genu [22].

Czynniki ERF uczestniczą w przystosowaniu roślin do stresu hipoksji poprzez uruchomienie strategii ucieczki lub spoczynku $[8,23]$. Większość z nich w warunkach fizjologicznych ulega ekspresji na niskim poziomie, natomiast silny wzrost ekspresji mogą indukować hormony i bodźce stresowe [21]. Z pięciu znanych czynników ERF u Arabidopsis thaliana biorących udział w odpowiedzi na hipoksję, RAP2.2, RAP2.3 i RAP2.12 ulegają ekspresji konstytutywnej, natomiast ekspresja HRE1 i HRE2 (ang. hypoxia responsive ERF) jest indukowana stresem. Ekspresja genów HRE1 i HRE2 jest zależna od poziomu tlenu w komórce i ulega silnemu wzrostowi przy niedotlenieniu, a następnie obniża się po 4-8 godzinach, w zależności od rodzaju tkanki [24]. Aktywność czynników ERF transkrybowanych konstytutywnie jest regulowana głównie potranslacyjnie. Unikalną cechą tej grupy białek jest obecność konserwowanej N-koncowej domeny (MCGGAII/L), której modyfikacje zależą głównie od stężenia $\mathrm{O}_{2}$ i NO, i mogą prowadzić do stabilizacji lub destabilizacji ERF zgodnie z regułą N-końca (NERP, ang. $\mathrm{N}$-end rule pathway) (Ryc. 1). Koniec $\mathrm{N}$ z metioniną jest substratem dla NERP [20]. W warunkach fizjologicznych pierwszy etap tego procesu polega na kotranslacyjnym usunięciu metioniny przez cytozolową aminotransferazę metioninową (MetAP, ang. Met-aminopeptidase enzymes). Następnie, pozostała na N-końcu grupa tiolowa cysteiny jest przekształcana do kwasu Cys-sulfinowego. Etap ten przeprowadzają oksydazy cysteinowe (PCO, ang. plant cysteine oxidase) $[22,25]$. Do utlenionej cysteiny transferaza arginylowa tRNA (ATE1/2, ang. arginyl tRNA transferase, ) przyłącza następnie argininę, po czym koniec N-Arg-ERFVII jest rozpoznawany przez enzym PRT6 (ang. proteolysis 6) oraz ligazy ubikwitynowe typu E3, a następnie degradowany $\mathrm{w}$ proteasomach 26S [22].
U A. thaliana wykryto 5 takich enzymów, których kofaktorem jest tlen i dlatego uważa się, że białka te mogą być jednym z molekularnych sensorów niedotlenienia. Wyciszenie dwóch najsilniej ulegających ekspresji genów, PCO1 i PCO2, powoduje indukcję genów odpowiedzi na hipoksję nawet $\mathrm{w}$ warunkach optymalnego stężenia tlenu, natomiast nadekspresja PCO1 lub PCO2 wyłącza ich aktywność podczas hipoksji [25].

Obecność 5 genów o różnym tkankowym poziomie ekspresji oraz ponad 200 białek z końcową cysteiną u Arabidopsis sugeruje dodatkowe funkcje dla PCO niż tylko regulacja czynników ERF związanych z niedotlenieniem. Ostatnio wykazano, że przyłączenie tlenu do N-końcowej cysteiny może przeprowadzać także oksydaza tiolowa ADO (ang. cysteamine (2-aminoethanethiol) dioxygenase), obecna także $\mathrm{w}$ komórkach człowieka [26].

Aktywność czynników ERF reguluje także zmiana miejsca ich lokalizacji w komórce. Mechanizm ten jest dobrze poznany na przykładzie czynników transkrypcyjnych RAP2.3 i RAP2.12 [22]. W warunkach fizjologicznych, konstytutywnie eksprymowany RAP2.12 jest wiązany do błony komórkowej poprzez białka ACBP1 i ACBP2 (ang. acyl-CoA binding protein). Zapobiega to degradacji RAP2.12, przez nieznany dotychczas mechanizm. Natomiast, przedwcześnie bądź przypadkowo uwolniony z błony cytoplazmatycznej ERF, podlega opisanej powyżej regule N-końca. ACBP to ewolucyjnie konserwowane białka obecne u wszystkich badanych dotąd eukariotów, biorące udział w sekwestracji i transporcie acylo-CoA [27]. RAP2.12 wiąże się przez fragment mający powinowactwo do DNA z powtarzającą się $\mathrm{w}$ ACBP1 domeną ankiryn. W przypadku hipoksji RAP2.12 jest uwalniany z błony komórkowej i transportowany do jądra komórkowego, gdzie aktywuje transkrypcję genów odpowiedzi na niedotlenienie. Proces ten uruchamia acylo-CoA, którego funkcję sygnałową po raz pierwszy wykryto u roślin badając właśnie procesy niedotlenienia. Podczas hipoksji wzrasta ilość C18:1-CoA, który jest formą przekaźnikową kwasów tłuszczowych syntetyzowanych w plastydach, podczas ich transportu do retikulum endoplazmatycznego, w którym zachodzi biogeneza lipidów. Po połączeniu C18:1-CoA z ACBP zmienia się konformacja białka błonowego i następuje uwalnianie RAP2.12 do cytoplazmy, a następnie jego transport do jądra komórkowego. Natomiast usunięcie warunków beztlenowych w ciągu godziny powoduje degradację białka w jądrze komórkowym [28].

U ryżu czynniki ERF regulujące hipoksję występują w locus SUB1. Znajdują się 3 geny $w$ tym locus tj. SUB1A, SUB1B i SUB1C. SUB1B i SUB1C występują u wszystkich badanych odmian ryżu natomiast SUB1A tylko u niektórych odmian podgatunku indyjskiego tolerancyjnych na zalewania. Znane są dwa allele SUB1A (SUB1A-1 i SUB1A-2), różniące się tylko jednym aminokwasem w obrębie regionu kodującego. Przy czym SUB1A-1 jest silnie transkrybowany i występuje $\mathrm{u}$ odmian tolerancyjnych natomiast SUB1A-2 występuje $\mathrm{u}$ odmian wrażliwych na zalewanie a jego ekspresja jest na niskim poziomie [29]. Wysoki poziom etylenu wraz z niskim poziomem tlenu oraz ATP powodują ponad dwustukrotny wzrost mRNA SUB1A [30]. Działanie SUB1A odbywa się m. 
in. poprzez stymulację syntezy brasinosteroidów (BR, ang. brassinosteroids). BR we wczesnej odpowiedzi na hipoksję (1 dzień zanurzenia roślin) zwiększają ekspresję genu GA2ox7 (ang. gibberellin 2-oxidase 7), który rozkłada gibereliny. Natomiast przy dłuższym niedotlenieniu BR indukują ekspresję genu SLR1 (ang. SLENDER RICE1), który z kolei obniża poziom transkryptów genów regulowanych przez kwas giberelinowy [31]. Wskazuje to, że wzajemne oddziaływanie między etylenem, BR i GA (ang. gibberellin) hamuje wzrost pędów w zanurzonym w wodzie ryżu. SUB1A wpływa także na gospodarkę zasobami węgla podczas strategii spoczynku. W przeciwieństwie do roślin, u których dominuje strategia ucieczki i następuje silne uruchomienie magazynów węgla zawartych $\mathrm{w}$ ziarnach skrobi, w genotypie $\mathrm{z}$ SUBA1 wykazano niższy poziom transkryptów a-amylazy [32]. Dodatkowo, wykazano także obniżenie degradacji chlorofilu, którego produkty rozkładu mogą również stanowić substraty dla oksydacji w mitochondriach. Zauważono także, że niższe tempo rozkładu chlorofilu przyczynia się do szybszej rekonstrukcji aparatu fotosyntetycznego po wystawieniu roślin z wody. SUB1A powoduje wolniejsze wykorzystanie magazynów węgla (w tym skrobi), a tym samym przedłuża okres przeżycia roślin zanurzonych $\mathrm{w}$ wodzie [32].

SUB1A nie ulega degradacji w komórkach ryżu wzrastającego w warunkach fizjologicznych. Pomimo że posiada kanoniczny koniec N, unika ścieżki NERP w warunkach optymalnego stężenia tlenu (Ryc. 1). Jak wykazał Lin i wsp. (2019) [33], koniec N jest maskowany poprzez interakcje z końcem C SUB1A. Mechanizm ten może wynikać z udziału SUB1A również w odpowiedzi rośliny na stres oksydacyjny, suszy czy stres wywołany etanolem [32]. Musi zatem występować odmienna ścieżka metaboliczna związana z aktywnością SUB1A w różnych stresach abiotycznych. Ostatnio wykazano, że SUB1A przyłącza się do promotorów genów ERF66 i ERF67, stymulując ich transkrypcję. Natomiast ERF66 i ERF67 są degradowane zgodnie $\mathrm{z}$ regułą $\mathrm{N}$ końca w warunkach braku deficytu tlenowego (Ryc. 1). Wynika z tego, że SUB1A podczas wzrostu ryżu w warunkach optymalnego stężenia tlenu nie ulega degradacji, a tym samym może regulować dodatkowo inne stresy abiotyczne. Nie wpływa to na uruchomienie odpowiedzi na hipoksje, ponieważ czynniki ERF indukowane przez SUB1A są degradowane przez proteasom [30].

Natomiast $\mathrm{u}$ odmian ryżu rosnącego w środowisku, gdzie utrzymuje się wysoki poziom wody przez długi czas, obecny jest locus SNORKEL, który koduje dwa geny należące do czynników ERF-VII: SK1 (ang. SNORKEL1) i SK2 (ang. SNORKEL2) [34]. Ekspresja SK1/SK2 sprzyja szybkiemu wzrostowi zatopionego ryżu, nawet do $25 \mathrm{~cm}$ na dobę. Podobnie jak w przypadku SUB1 regulacja aktywności transkrypcyjnej SK odbywa się przez etylen. W wyniku kaskady sygnalizacyjnej uruchamianej przyłączeniem się ET do receptorów następuje wiązanie EIL1B (ang. protein ethylene-insensitive 3-like 1b) do promotorów i uruchomienie transkrypcji SK. W wyniku aktywności SK w międzywęźlach gromadzi się kwas giberelinowy i następuje intensywny wzrost pędu [32,35].

\section{ANALIZA TRANSKRYPTOMU ROŚLIN PODDANYCH NIEDOTLENIENIU}

Od kilku lat prowadzone są badania nad odpowiedzią roślin na stres hipoksji na poziomie transkryptomu. Badania prowadzone są na różnych gatunkach roślin, ekotypach A. thaliana, organach oraz z uwzględnieniem różnorodnych metod wprowadzania roślin w stres niedotlenienia. Porównanie transkryptomów 21 różnych typów komórek w korzeniach i pędach $A$. thaliana pozwoliło ustalić listę 49 niezmiennych genów odpowiedzi na stres hipoksji. Ekspresja większość z nich jest związana ze zmianą metabolizmu w celu zwiększenia ilość substratu dla produkcji ATP, a także uruchomieniem oddychania beztlenowego. Wśród tych genów są m. in: SUS4 (ang. sucrose synthase 4) i inne geny syntetaz sacharozy, gen PFK4 -ATP zależnej fosfofruktokinazy (ang. phosphofructokinase), dehydrogenaz pirogronianowych PDC1 (ang. pyruvate decarboxylase 1) i PDC2 (ang. pyruvate decarboxylase 2), dehydrogenazy alkoholowej ADH1, czy transporteru mleczanu LDH (ang. lactate dehydrogenase) [36].

W warunkach beztlenowych wykazano wzrost poziomu ekspresji enzymów zwiększających ilość glukozy, która jest substratem w glikolizie tj. inwertaz biorących udział w rozkładzie sacharozy oraz $\beta$-amylazy. Podczas glikolizy z jednej cząsteczki glukozy powstają 2 cząsteczki ATP, natomiast oddychanie tlenowe generuje 30 cząsteczek ATP z jednej cząsteczki glukozy. W procesie tym jest wykorzystywany $\mathrm{NAD}^{+}$, podczas przekształcenia aldehydu 3-fosfoglicerynowego do 1,3-bifosfoglicerynianu. Następnie, po przeniesieniu grupy fosforanowej na ADP, powstaje ATP. Procesom tym towarzyszy fermentacja, podczas której zostaje odtworzony $\mathrm{NAD}^{+}$, niezbędny w procesie glikolizy. U roślin głównym typem fermentacji jest fermentacja alkoholowa, a za jej przeprowadzenie odpowiedzialny jest enzym dehydrogenaza alkoholowa ADH1, będąca uniwersalnym markerem hipoksji. Silny wzrost poziomu mRNA kodującego ADH1 obserwowano we wszystkich dotychczasowych badaniach stresu hipoksji u roślin [36]. Podczas stresu niedotlenienia obserwowano także wzrost poziomu kwasu gamma-aminomasłowego (GABA, ang. gamma aminobutyric acid) w korzeniach $A$. thaliana. GABA należy do aminokwasów niebiałkowych, wytwarzanych w warunkach niedotlenienia w cytozolu, w wyniku dekarboksylacji L-glutaminianu przez dekarboksylazę glutaminianową (GAD, ang. glutamate decarboxylase) z udziałem jonów $\mathrm{Ca}^{2+}$ i kalmoduliny. Spośród 5 genów kodujących mRNA GAD u A. thaliana, GAD1 występuje tylko w korzeniach, GAD2 ulega konstytutywnej ekspresji we wszystkich organach a GAD3-5 jest słabo indukowany $\mathrm{w}$ tkance wegetatywnej [36]. Podczas niedotlenienia korzeni obserwuje się wzrost aktywności GAD4 i spadek GAD2. Podczas hipoksji u roślin kwas gamma-aminomasłowy gromadzi się początkowo w cytoplazmie, skąd jest następnie transportowany do mitochondrium. Dlatego też GABA stanowi substrat zarówno w cyklu kwasów trójkarboksylowych (TCA, ang. tricarboxylic acid cycle), jak i w łańcuchu transportu elektronów, dzięki czemu uczestniczy w produkcji energii i utrzymaniu równowagi węglowo-azotowej. Dodatkowo, wykorzystywanie przez GAD protonów do syntezy GABA skutkuje podwyższeniem $\mathrm{pH}$ w komórce. $W$ ten sposób komórki roślinne bronią się przed zakwaszeniem środowiska na skutek przeprowadzanej fer- 
mentacji w warunkach niedotlenienia. Wykazano, że niskie pH aktywuje GAD, dzięki czemu zwiększa się poziom jego ekspresji w komórce w odpowiedzi na stres hipoksji [36].

GABA reguluje także konwersję pirogronianu, który reaguje $\mathrm{z}$ glutaminianem prowadząc do powstania alaniny i 2-oksoglutaranu [36]. Reakcja ta jest katalizowana przez aminotrasferazę alaninową (ALAT, ang. alanine aminotransferase), której poziom ekspresji, zwiększa się podczas stresu hipoksji. Następnie 2-oksoglutaran jest włączany do cyklu Krebsa, gdzie zostaje przekształcony w bursztynian i ATP, z wykorzystaniem $\mathrm{NAD}^{+}$jako przekaźnika elektronów. Taka reorganizacja cyklu kwasu trójkarboksylowego, którą poprzedzają zmiany $\mathrm{w}$ transkryptomie, prowadzi do powstania dwóch dodatkowych cząsteczek ATP. Oznacza to, że w warunkach beztlenowych, uwzględniając produkty glikolizy, końcowa ilość ATP zwiększa się do czterech cząsteczek. Dlatego można uznać ten szlak za równie istotny w odpowiedzi na hipoksję, co szlaki fermentacyjne [36,37].

Podczas hipoksji następuje również wzrost ekspresji genów biorących udział $\mathrm{w}$ biogenezie tlenku azotu (NO, ang. nitric oxide). Przyczynia się do tego obniżenie $\mathrm{pH}$, w wyniku czego akumulowane są azotany, które są rozkładane do tlenku azotu przez enzym reduktazę azotanową (NR, ang. nitrate reductase). Badania transkryptomiczne i biochemiczne ujawniły, że niedotlenienie prowadzi, kolejno, do wzrostu aktywności reduktazy azotanowej NR1 (ang. nitrate reductase 1) i NR2 (ang. nitrate reductase 2), produkcji NO a następnie syntezy fitoglobiny klasy 1 (PGB1, ang. phytoglobin1) [37]. Roślinne niesymbiotyczne hemoglobiny uznawane są za jeden ze znanych sensorów niedotlenienia i biorą udział w rozkładzie NO. Obniżenie stężenia tlenku azotu i tlenu zatrzymuje także degradację czynników ERF w warunkach beztlenowych. NO bierze także udział w zwiększeniu intensywności procesu fermentacji, recyklingu $\mathrm{NAD}^{+}$i redukcji zakwaszenia komórki m.in. poprzez cykl oddechowy Pgb-NO (ang. phytoglobin-nitric oxide), uważany za alternatywną droge procesu fermentacji. Cykl fitoglobina-tlenek azotu związany jest z utlenianiem NADH i utrzymaniem odpowiedniego poziomu ATP w warunkach niedotlenienia. Polega na usuwaniu NO przez oksyfitoglobinę $\left(\mathrm{Pgb}\left(\mathrm{Fe}^{2+}\right) \mathrm{O}_{2}\right)$, a następnie na jej regeneracji przez białko reduktazy metfitoglobiny (MetPgb-R) [37]. Wytwarzanie NO w warunkach hipoksji prowadzi także do aktywacji genów kodujących syntazę ACC (ang. ACC synthase) i oksydazę ACC (ang. ACC oxidase), wymaganych do biosyntezy etylenu oraz genów odpowiedzi na etylen ERF1 (ang. ethylene response factor 1) i PDF13 (ang. plant defensin 13) [38].

Ostatnio zastosowano nowe techniki sekwencjonowania transkryptomu w badaniach nad hipoksją. Metoda profilowania rybosomów połączona $\mathrm{z}$ wysokoprzepustowym sekwencjonowaniem (Ribo-seq) pozwoliła określić, które z transkrybowanych RNA ulegają translacji. Technika ta polega na sekwencjonowaniu fragmentów RNA (tzw. odcisków rybosomów), które były chronione przez rybosom i nie uległy degradacji przez nukleazy. Dodatkowo, wyprowadzono mutanta $A$. thaliana $\mathrm{z}$ nadekspresją rybosomowego białka L18 z metką FLAG [39]. Techniką immunopercypitacji izolowano kompleksy rybosomów wraz z fragmentami mRNA znajdującymi się pomiędzy dużą i małą podjednostką. Uzy- skaną w ten sposób część transkryptomu nazwano translatomem. Wykazano, że dwugodzinna hipoksja zmniejszała o 47\% liczbę polisomów na korzyść monosomów, potwierdzając mechanizm obniżenia poziomu translacji [15, 40]. Dodatkowo, w porównaniu z roślinami rosnącymi w warunkach fizjologicznych, $w$ translatomie tym było mniej sekwencji zawierających kodon AUG, co wskazuje na silne obniżenie inicjacji translacji. Niemniej jednak, potwierdzono translację wszystkich podstawowych białek kodowanych przez geny odpowiedzi na stres hipoksji [40].

W translatomie obecne są także sekwencje występujące w krótkich ramkach odczytu (uORF, ang. upstream ORFs). $\mathrm{W}$ translatomie roślin po hipoksji zidentyfikowano 51 genów, w przypadku których obecność rybosomów na uORF zmniejszała poziom wykorzystania głównej ramki odczytu. Podczas hipoksji zauważono także zmianę wzorca alternatywnego splicingu (AS, ang. alternative splicing). Jak wiadomo, AS dotyczy ok. $60 \%$ genów zawierających introny $\mathrm{u}$ roślin a najczęstszym zdarzeniem splicingowym jest retencja intronów [41]. Podczas hipoksji, 5\% sekwencji translatomu było mapowanych do intronów. Retencja intronów dotyczy często czynników splicigowych i regulatorów cyklu dobowego. W przypadku białka GRP7 (ang. glycine-rich RNA-binding protein (GRP7)/cold circadian rhythm) i CCR2 (ang. RNA-binding protein 2), nieusunięciu intronu $\mathrm{z}$ pre-mRNA towarzyszy spadek intensywności translacji. W pierwszych intronach obu transkryptów znajduje się przedwczesny kodon terminacji (PTC, ang. premature termination codons), który powoduje degradację RNA na drodze NMD (ang. nonsense-mediated decay). W translatomie A. thaliana zidentyfikowano także obecność pojedynczych niekodujących RNA (ncRNA, ang. non-coding RNA) wśród nich anty-sensownych ncRNA i długich intergenowych ncRNA [40].

Ostatnio Lorenzo i wsp [42] wskazali również alternatywne miejsca poliadenylacji (APA, ang. alternative polyadenylation) jako ważny etap regulacji ekspresji genów podczas hipoksji. Stres niedotlenienia powoduje zwiększenie izoform mRNA z niekanonicznymi miejscami poliadenylacji $\mathrm{w}$ sekwencji kodującej, intronach czy nawet rejonach 5' UTR. Pierwsza kategoria transkryptów jest bardzo niestabilna i ulega degradacji. Podobnie jak w przypadku alternatywnego splicingu, funkcję APA upatruje się w regulacji ilości kanonicznych form mRNA. Przy podobnej intensywności procesu transkrypcji, generowanie izoform poszczególnych genów z odmiennym miejscem poliadenylacji (które zwykle są niefunkcjonalne lub mniej stabilne) zmniejsza ilość mRNA kodujących prawidłową formę białka [42].

Ważnym elementem odpowiedzi na stres abiotyczny jest regulacja ekspresji genów kluczowych dla tego procesu przez miRNA [43]. W stresie hipoksji miRNA regulują procesy kwitnienia, adaptacji morfologicznych, zmiany $\mathrm{w}$ zasobach energetycznych oraz odpowiedzi na stres oksydacyjny rośliny [19].

miRNA biorą także udział w utrzymaniu równowagi pomiędzy odpowiedzią na stres wywołany powodzią, a prawidłowym rozwojem rośliny poprzez szlaki sygnalizacji hormonalnej. Analiza promotorów genów miRNA ujawniła obecność elementów regulowanych in cis przez auksyny, 
etylen, GA i ABA (ang. abscisic acid) [44]. U roślin stwierdzono obecność kilku mikroRNA zależnych od niedotlenienia, których docelowe mRNA kodują czynniki transkrypcyjne wpływające na adaptację do warunków stresowych poprzez zmiany morfologiczne $\mathrm{w}$ tkankach. W korzeniach kukurydzy hipoksja powoduje wzrost ekspresji miR159 i zmniejszenie poziomu mRNA GAMYBs, MYB33 i MYB101. Badania prowadzone $\mathrm{u} A$. thaliana potwierdziły, że miR159 kontroluje poziom czynników transkrypcyjnych MYB33, MYB101 i MYB65, które powodują zahamowanie wzrostu korzenia głównego [19]. Wykazano także udział miR390 i auksyn we wzroście korzeni podczas hipoksji [45]. miR390 ulega ekspresji $\mathrm{w}$ momencie rozpoczęcia wzrostu korzeni bocznych, wywołując tkankowo specyficzną produkcję tasiRNA (ang. trans-acting small interfering RNA). Wykazano doświadczalnie, iż miR390 działa poprzez TAS3, z którego produkowane są cząsteczki tasiRNA3, hamujące ekspresję czynników transkrypcyjnych ARF (ang. auxin response factor). Badania na mutancie tas3a-1 A. thaliana, zawierającym tylko $40 \%$ transkryptu TAS3 w stosunku do rośliny typu dzikiego dowiodły, że zmniejszony poziom TAS3 wywołuje skrócenie korzeni bocznych. Natomiast mutant, u którego poziom transkryptu TAS3 był 100 krotnie wyższy w porównaniu do roślin typu dzikiego charakteryzował się 1,5 razy dłuższymi korzeniami. Badania ujawniły, że miR390 i tasiRNA3 gromadzą w się w miejscu inicjacji wzrostu korzeni bocznych blokując ekspresję genów $A R F$, co powoduje wydłużenie korzeni. Ponadto, ARF kontroluje ekspresje miR390 indukowaną auksynami. W ten sposób powstaje pętla sprzężenia zwrotnego, regulująca poziom ARF oraz kontrolująca optymalny rozwój korzeni w warunkach ograniczonej dostępności tlenu [45].

Powodzie prowadzą do ograniczenia oddychania tlenowego i fotosyntezy, powodując zubożenie zasobów energetycznych roślin. Utrzymanie odpowiedniego poziomu energii $\mathrm{w}$ takich warunkach jest możliwe, między innym, dzięki zahamowaniu syntezy skrobi i indukcji jej rozkładu. W przypadku siewek L. japonicus oraz kukurydzy, zatopienie powoduje zmniejszenie poziomu miR399, co skutkuje zwiększeniem ilości ich docelowego mRNA kodującego $\beta$-amylazę [46]. U kukurydzy wykazano także obniżenie poziomu miR159, miR395, miR474 i wzrost ich przewidywanych docelowych mRNA tj. mRNA białek: wakuolarnej ATPazy, hydrolazy glikozydowej i sulfurylazy ATP [44]. Białka te biorą udział $\mathrm{w}$ podstawowych procesach energetycznych podczas stresu, takich jak produkcja ATP, homeostaza $\mathrm{pH}$, zwiększenie przyswajalności siarki, rozpad węglowodanów i regulacja ilości pirogronianu.

Kwitnienie to kolejny proces wymagający dużej ilości energii, której ilość ograniczona jest w trakcie powodzi. Zatem opóźnienie kwitnienia oraz rozwoju kwiatów można uznać za kolejną strategię oszczędzania zasobów energetycznych $\mathrm{w}$ warunkach stresu. W przypadku siewek $L$. japonicus miR319 zmniejsza poziom genu TCP4 (ang. TEOSINTE BRANCHED/CYCLOIDEA/PROLIFERATING CELL FACTORS), którego produkt jest jednym $\mathrm{z}$ negatywnych regulatorów cyklu komórkowego i ma kluczowe znaczenie dla wzrostu i rozwoju płatków [46]. Wykazano także wzrost ilości miR156, który kontroluje ekspresję mRNA czynników transkrypcyjnych SPL (ang. squamosa promoter binding pro- tein-like). Czynniki SPL natomiast regulują wzrost korzeni ale także indukują kwitnienie, wielkość organów kwiatu i rozwój owoców [19].

$\mathrm{W}$ trakcie powodzi zahamowanie oddychania tlenowego prowadzi do wytworzenia reaktywnych form tlenu. W celu utrzymania ich na odpowiednim poziomie, $\mathrm{w}$ roślinie aktywowane są enzymy utleniania/redukcji, wiążące jony miedzi, takie jak cupredoksyny. Plastocyjanina, lakaza oraz dysmutaza ponadtlenkowa (SOD, ang. superoxide dismutase) zawierają domeny cupredoksyny, które są konserwowanymi celami dla miR408, miR528 i miR397. W korzeniach kukurydzy podczas długotrwałego zanurzenia $\mathrm{w}$ wodzie wykazano obniżony poziom miR528 [44]. Natomiast w przypadku krótkotrwałej hipoksji poziom miR528 i miR408 ulega podwyższeniu [47]. Odzwierciedla to ustalenie równowagi pomiędzy funkcją sygnalizacją reaktywnych form tlenu a ich toksycznością.

\section{PRZESTRZENNA REGULACJA EKSPRESJI GENÓW PODCZAS HIPOKSJI.}

Potranskrypcyjne procesy towarzyszące mRNA są niezwykle ważne $\mathrm{w}$ warunkach stresu abiotycznego [41]. Już podczas syntezy, mRNA łączy się z różnymi typami białek RBP (ang. RNA binding protein), które mogą istotnie wpływać na alternatywny splicing, alternatywne miejsca poliadenylacji, translację, czy ostatecznie na degradację. Ostatnio na nowo odkrywa się wpływ lokalizacji komórkowej RNA na regulację ekspresji genów. Naturalną barierą odgradzającą miejsce syntezy transkryptu od miejsca translacji jest otoczka jądrowa. Dlatego tempo kumulacji mRNA w jądrze komórkowym czy transportu do cytoplazmy decyduje o czasie powstania białka. Co więcej, obecność mRNA w cytoplazmie nie gwarantuje syntezy białka. Znaczna ilość mRNA nie jest połączona $\mathrm{z}$ rybosomami, a niekiedy może także ulec sekwestracji w strukturach cytoplazmatycznych $[40,48]$.

Podczas niedotlenienia następuje zatrzymanie poliadenylowanych RNA (poliA RNA) w jądrze komórkowym, czemu towarzyszy obniżenie poziomu transkrypcji (Ryc. 2). Wykazano, że $\mathrm{w}$ procesie tym mogą uczestniczyć jądrowe ciała Cajala (CB, ang. Cajal bodies), związane z metabolizmem różnych typów RNA. Mutanty ncb-1 A. thaliana, pozbawione $\mathrm{CB}$, są mniej tolerancyjne na niedotlenienie $\mathrm{w}$ porównaniu $\mathrm{z}$ roślinami typu dzikiego [49]. Co ciekawe, w jądrach komórkowych L. luteus i A. thaliana gromadzą się mRNA białek, których udziału w odpowiedzi na hipoksję jak dotąd nie wykazano. Z kolei, mRNA $\mathrm{ADH} 1$ po procesie transkrypcji jest od razu transportowany do cytoplazmy. Po usunięciu deficytu tlenowego, mRNA, nagromadzone $\mathrm{w}$ jądrze komórkowym podczas hipoksji, są natychmiast transportowane do cytoplazmy. Wynika z tego, że może to być jedna ze strategii pomagająca roślinom $\mathrm{w}$ przetrwaniu niedotlenienia i szybkiego powrotu do właściwego metabolizmu po ponownym natlenieniu $[13,49]$. Obecnie retencję mRNA w jądrze komórkowym wykazano także w komórkach zwierząt, a znaczenie tego zjawiska, oprócz magazynowania RNA, upatruje się $\mathrm{W}$ regulacji pulsacyjnej transkrypcji genomu [50]. 

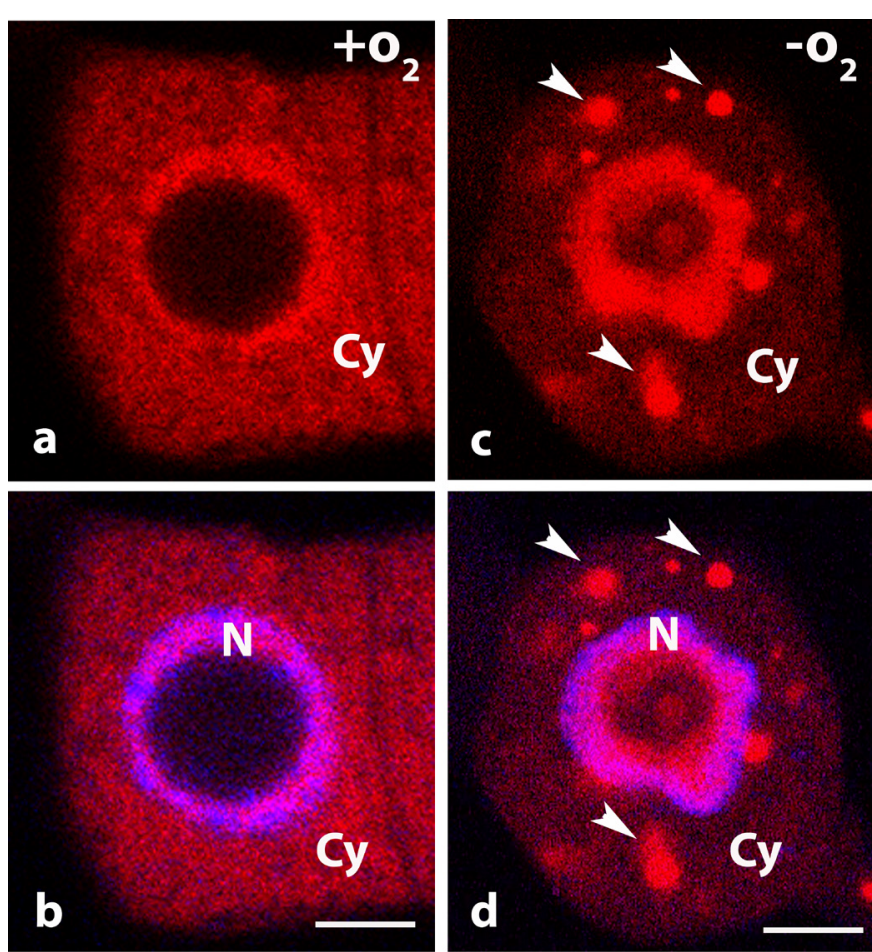

Rycina 2. Lokalizacja poli(A) RNA z zastosowaniem techniki hybrydyzacji in situ i sondy oligonukleotydowej znakowanej fluorochromem Cy3 (kolor czerwony) w komórkach korzeni Lupinus luteus rosnących w warunkach optymalnego stężenia tlenu $(\mathrm{a}, \mathrm{b}) \mathrm{i}$ hipoksji $(\mathrm{c}, \mathrm{d})$. Podczas niedotlenienia następuje kumulacja poli(A) RNA w jądrze komórkowym i w strukturach cytoplazmatycznych przypominających granule stresowe (groty strzałek). b, d - jednoczesna lokalizacja poli(A) RNA i barwienie DNA z użyciem DAPI (kolor niebieski); N - jądro komórkowe; Cy - cytoplazma; Bar $5 \mu \mathrm{m}$; (Niedojadło J, niepublikowane).

Stosując wspomnianą powyżej technikę Ribo-seq można porównać całkowitą ilość mRNA w komórce ze stopniem jego wykorzystania w translacji. U A. thaliana ilość całkowitego mRNA w komórce spada o 4,2\% po dwóch godzinach, i o $22 \%$ po 9 godzinach hipoksji. Natomiast, $\mathrm{w}$ tych samych godzinach traktowania roślin stresem niedotlenienia występowało obniżenie asocjacji mRNA z rybosomami, odpowiednio o $67 \%$ i $73 \%$. Wskazuje to, że rośliny poddane niedotlenieniu oszczędzają ATP poprzez silną redukcję procesu translacji [15]. Natomiast dla genów uznawanych za znacznikowe dla stresu hipoksji, takich jak LDH czy ADH1, obserwowano zarówno wzrost wydajności na poziomie transkrypcji jak i translacji. Znane są również takie mRNA, których poziom wzrasta podczas hipoksji, jednak ich wzmożona translacja zachodzi dopiero po usunięciu deficytu tlenowego. Można to tłumaczyć przygotowaniem roślin na poziomie transkryptomu do wyjścia ze stresu. Do takich transkryptów należy m.in. mRNA dehydrogenezy semialdehydu bursztynianowego, przekształcającego semialdehyd bursztynianowy do bursztynianu [15], czy mRNA białka RPB2 (ang. RNA polymerase II gene subunit), drugiego pod względem wielkości polipeptydu polimerazy II RNA [13,40]. Zatem rozdzielenie mRNA od aparatu translacyjnego w cytoplazmie skutkuje wybiórczą syntezą białka, a zjawisko to można uznać za kluczowy mechanizm kontroli ekspresji genów i zachowania energii w odpowiedzi na niedotlenienie.
Kolejnym mechanizmem przestrzennej organizacji transkryptomu jest gromadzenie mRNA w strukturach cytoplazmatycznych. Najlepiej poznanymi strukturami są ciała P (PBs, ang. processing body) i granule stresowe (SG, ang. stress granules). Ciała PBs występują u wszystkich eukariontów, brak w nich pełnej maszynerii translacyjnej i są one miejscem segregacji, magazynowania oraz degradacji mRNA. Natomiast $\mathrm{w}$ warunkach stresu powstają, niekiedy $\mathrm{w}$ przeciągu minut, granule stresowe. $\mathrm{W}$ przypadku niedotlenienia $\mathrm{w}$ liściach $A$. thaliana obserwowano granule stresowe bogate $\mathrm{w}$ białko UBP1C (ang. oligouridylate binding protein 1C). UBP1C zawiera potrójny motyw wiążący RNA RRM (ang. RNA recognition motif) i jest ortologiem zwierzęcego białka TIA-1 (ang. T-cell intracellular antigen 1), biorącego udział w powstaniu ciał SG. W warunkach optymalnego stężenia tlenu UPB1C wiąże bogate w urydynę sekwencje występujące w rejonie 3' UTR, natomiast podczas hipoksji białko to tworzy ciała SG i asocjuje $\mathrm{z}$ RNA nieposiadającymi sekwencji bogatych w urydynę. Zjawisko to koreluje z obserwowaną redukcją syntezy odpowiednich białek. Ponadto wykazano, że mutanty ubp $1 c$ były mniej tolerancyjne niż rośliny typu dzikiego na stres niedotlenienia [48]. Podczas hipoksji w komórkach korzeni Lupinus luteus obserwowano także duże cytoplazmatyczne struktury bogate w poli(A) RNA (Ryc. 2), ale niezawierające $26 S$ rRNA. Na terenie tych struktur, przypominających ciała SG, występowały transkrypty niezwiązane $\mathrm{z}$ odpowiedzią na hipoksję. Z kolei, mRNA ADH1 lokalizowano na obszarze cytoplazmy, gdzie mogło ulegać translacji [13]. Wskazuje to na udział SG w regulacji wybiórczej translacji mRNA w stresie niedotlenienia. Jednakże, ciągle nie znamy pełnego składu transkryptomów cytoplazmatycznych ciał SG ani PB, oraz wzajemnych relacji obu struktur u roślin rosnących $\mathrm{w}$ warunkach hipoksji.

\section{PIŚMIENNICTWO:}

1. Sasidharan R, Bailey-Serres J, Ashikari M, Atwell BJ, Comer T D, Fagerstedt K (2017) Community recommendations on terminology and procedures used in flooding and low oxygen stress research. New Phytol 214: 1403-1407

2. Lee SC, Mustroph A, Sasidharan E, Vashisht D, Pedersen O, Oosumi T (2011) Molecular characterization submergence response of the Arabidopsis thaliana ecotype Columbia. New Phytol 190: 457-471

3. Hartman K, Tringe SG (2019) Interactions between plants and soil shaping root microbiome under abiotic stress. Biochem J 476: 27052724

4. Phukan UJ, Mishra S, Shukala RK (2016) Waterlogging and sumbergence stress: affects and acclimation. Crit Rev Biotechnol 36: 956-966

5. Bailey-Serres J, Lee ChS, Brinton E (2012) Waterproofing crops: effective flooding survival strategies. Plant Physiol 160: 1698-1709

6. Stricker GG, Casas C, Kuang X, Grimoldi AA (2017) No escape? Costs and benefits of leaf de-submergence in the pasture grass Chloris gayana under different flooding regimes. Funct Plant Biol 44: 899-906

7. Rehman A, Jingdong L, Du Y, Khatoon R, Wagan SA, Nisar SK (2015) Flood disaster in Pakistan and it impact on agriculture growth (a review). Environ Dev Econ. 6:39-42

8. Voesenek LACJ, Bailey-Serres J (2015) Flood adaptive traits and processes: an overview. New Phytol 206: 57-73

9. Loreti E, van Veen H, Perata P (2016) Plant responses to flooding stress. Curr Opin Plant Biol 33: 64-71

10. Rauf M, Arif M, Fisahn J, Xue GP, Balazadeh S, Mueller Roeber B (2013) NAC transcripion factor speedy hyponastic growth regulates flooding-induced leaf movement in Arabidopsis. Plant Cell 25: 49414955 
11. Pierik R, van Aken JM, Voesenek LACJ (2009) Is elongation-induced leaf emergence beneficial for submerged Rumex species? Ann Bot 103: 353-357

12. Schulze ED, Beck E, Buchmann N, Clemens S, Müller-Hohenstein K, Scherer-Lorenzen M (2019) Oxygen deficiency. Plant Ecol 1: 143-164

13. Niedojadło J, Dełeńko K, Niedojadło K (2016) Regulation of poly(A) RNA retention in the nucleus as survival strategy of plants during hypoxia. RNA Biol 13: 531-543

14. Ortmann B, Druker J, Rocha S (2014) Cell cycle progression in response to oxygen levels. Cell Mol Life Sci71: 3569-3582

15. Branco-Price C, Kaiser KA, Jang CJH, Larive CK, Bailey-Serres J (2008) Selective mRNA translation coordinates energetic and metabolic adjustments to cellular oxygen deprivation and reoxygenation in Arabidopsis thaliana. Plant J 56: 743-755

16. Akman M, Mustroph A, Bhikharie AV, Sasidharan R (2014) Extreme flooding tolerance in Rorippa. Plant Signal Behav 9: e27847

17. Jackson MB (2008) Ethylene-promoted elongation: an adaptation to submergence stress. Ann Bot 101(2): 229-248

18. Vanderstraeten L, Depaepe T, Bertrand S, Van Der Straeten D (2019) The Ethylene Precursor ACC Affects Early Vegetative Development Independently of Ethylene Singaling. Front Plant Sci. 10:1591

19. Fukao T, Barrera-Figueroa BE, Juntawong P, Peña-Castro (2019) Submergence and waterlogging stress in plants: a review highlighting research opportunities and understudied aspects. Front Plant Sci 10: 340

20. Nakano T, Suzuki K, Fujimura T, Shinshi H (2006) Genome-wide analysis of the ERF gene family in Arabidopsis and Rice. Plant Physiol 140: 411

21. Xie Z, Nolan TMN, Jiang H, Yin Y (2019) AP2/ERF transcription factor regulatory networks hormone and abiotic stress responses in Arabidopsis. Front Plant Sci 1: 228

22. Gibbs DJ, Conde JV, Berckhan S, Prasad G, Mendiondo GM, Holdsworth MJ (2015) Group VII ethylene response factors coordinate oxygen and nitric oxide signal transduction and stress responses in plants. Plant Physiol 169: 23-31

23. Pucciariello Ch, Perata P (2017) Flooding Stress Tolerance in Plants, W: Shabala S (red) Plant Stress Physiology. CABI, Croydon, UK, str. 155170

24. Licausi F, van Dongen JT, Giuntoli B, Novi G, Santaniello A, Geigenberger P, Perata P (2010) HRE1 and HRE2, two hypoxia-inducible ethylene response factors, affect anaerobic responses in Arabidopsis thaliana. Plant J 62: 302-315

25. White MD, Klecker M, Hopkinson RJ, Weits DA, Mueller C, Naumann C, O'Neill R, Wickens J, Yang J, Brooks-Bartlett JC (2017) Plant cysteine oxidases are dioxygenases that directly enable arginyl transferase-catalysed arginylation of N-end rule targets. Nat Commun 8: 14690

26. Masson N, Keeley TP, Giuntoli B, White MD, Puerta ML, Perata P, Hopkinson RJ, Flashman E, Licausi F, Ratcliffe PJ (2019) Conserved $\mathrm{N}$-terminal cystine dioxygenases transduce responses to hypoxia in animals and plants. Science 365: 65-69

27. Grevengoed TJ, Klett EL, Coleman RA (2014) Acyl-CoA metabolism and partitioning. Annu Rev Nutr 34: 1-30

28. Schmidt R, van Dogen J (2019) The ACBP1-RAP2.12 signalling hub: A new perspective on integrative signalling during hypoxia in plants. Plant Signal Behav 14: e1651184

29. Fukao T, Harris T, Bailey-Serres J (2009) Evolutionary Analysis of the Sub1 gene cluster that confers submergence tolerance to domesticated rice. Ann Bot 103(2): 143-150

30. Lin ChCh, Chao YT, Chen WCh, Ho HY, Chou MY, Li YR, Wu YL, Yang HA, Hsieh H, Lin ChS, Wu FH, Chou SJ, Jen HCh, Huang YH, Irene D, Wu WJ, Wu JL, Gibbs DJ, Ho MCh, Shih MCh (2019) Regulatory cascade involving transcriptional and $\mathrm{N}$-end rule pathways in rice under submergence. Proc Natl Acad Sci USA 116: 3300-3309

31. Schmitz AJ, Folsom J, Jikamaru Y, Ronald P, Walia H (2013) SUB1A-mediated submergence tolerance response in rice involves differential regulation of the brassinosteroid pathway. New Phytol 198: 10601070
32. Tamang BG, Fukao T (2015) Plant adaptation to multiple stresses during submergence and following desubmergence. Int J Mol Sci 16: 30164-30180

33. Chih-Cheng Lin, Ya-Ting Chao, Wan-Chieh Chen, Hsiu-Yin Ho, Mei-Yi Chou, Ya-Ru Li, Yu-Lin Wu, Hung-An Yang, Hsiang Hsieh, Choun-Sea Lin, Fu-Hui Wu, Shu-Jen Chou, Hao-Chung Jen, Yung-Hsiang Huang, Deli Irene, Wen-Jin Wu, Jian-Li Wu, Daniel J. Gibbs (2019) Regulatory cascade involving transcriptional and $\mathrm{N}$-end rule pathways in rice under submergence. Proc Natl Acad Sci USA 116: 3300-3309

34. Hattori Y, Nagai K, Furukawa S, Song XJ, Kawano R, Sakakibara $\mathrm{H}, \mathrm{Wu}$ J, Matsumoto T, Yoshimura A, Kitano H, Matsuoka M, Mori H, Ashikari M (2009) The etylene response factors SNORKEL1 and SNORKEL2 allow rice to adapt to deep water. Nature 460: 1023-1030

35. Xiong L (2013) Features comprehensive coverage of abiotic stress responses in plants, W: Ahmad P, Prasad MNV (red) Abiotic stress resistance. Springer Science, Switzerland, str: 193-215

36. Mustroph A, Barding AJR, Kaiser KA, Larive CK, Bailey-Serres J (2014) Characterization of distinct root and shoot responses to low-oxygen stress in Arabidopsis with a focus on primary C-and N-metabolism. Plant Cell Environ 37: 2366-2380

37. Gupta KJ, Mur LAJ, Wany A, Kumari A, Fernie AR, Ratcliffe G (2019) The role of nitrite and nitric oxide under low oxygen conditions in plants. New Phytol 225: 1143-1151

38. Wany A, Kumari A, Gupta KJ (2017) Nitric oxide is essential for the development of aerenchyma in wheat roots under hypoxic stress. Plant Cell Environ 40: 3002-3017

39. Reynoso MA, Juntawong P, Lancia M, Blanco FA, Bailey-Serres J, Zanetti ME (2015) Translating ribosome affinity purification (TRAP) followed by RNA sequncing technology (TRAP-SEQ) for quantitative assessment of plant translatomes. MIMB 1284: 185-207

40. Juntawong P, Girke T, Bazin J, Bailey-Serres (2014) Translational dynamics revealed by genome-wide profiling of ribosome footprints in Arabidopsis. Proc Natl Acad USA 111: e203-212

41. Laloum T, Martin G, Duque P (2018) Alternative splicing control of abiotic stress responses. Trends Plant Sci 23: 140-150

42. de Lorenzo L, Sorenson R, Bailey-Serres J, Hunt AG (2017) Noncanonical alternative polyadenylation contributes to gene regulation in response to hypoxia. Plant Cell 29: 1262-1277

43. Barciszewska-Pacak M, Milanowska K, Knop K, Bilewicz D, Nuc P, Plewka P, Pacak AM, Vazquez F, Karlowski W, Jarmolowski A, Szweykowska-Kulinska Z (2015) Arabidopsis microRNA expression regulation in a wide range of abiotic stress responses. Front Plant Sci 6: 410

44. Zhang Z, Wei L, Zou X, Tao Y, Liu Z, Zheng Y (2008) Submergence-responsive microRNAs are potentially involved in the regulation of morphological and metabolic adaptation in maize root cells. Ann Bot 102: 509-519

45. Marin E, Jouannet V, Herz A, Lokerse AS, Weijers D, Vacheret H, Nussaume L, Crespi MD, Maizel A (2010) miR390, Arabidopsis TAS3 tasiRNAs and theri auxin response factor targets define an autoregulatory network quantitatively regulating lateral root growth. Plant Cell 22: 1104-1117

46. Jin Q, Xu Y, Mattson N, Li X, Wang B, Zhang X, Jiang X, Liu X, Wang Y, Yao D (2017) Identification of submergence-responsive microRNA in their targets reveals complex miRNA-mediated regulatory networks in Lotus (Nelumbo nucifera Gaertn). Front Plant Sci 18: 8-6

47. Liu Z, Kumari S, Zhang L, Zheng Y, Ware D (2012) Characterization of miRNAs in there inbred lines of Zea mays. PLoS One.7(6): e39786

48. Sorenson R, Bailey-Serres J (2014) Selective mRNA sequestration by oligouridylate-binding protein 1 contributes to translational control during hypoxia in Arabidopsis. Proc Natl Acad Sci USA 111: 2373-2378

49. Niedojadło J, Kubicka E, Kalich B, Smoliński DJ (2014) Poly(A) RNAs including coding proteins RNAs occur in plant Cajal bodies. PLoS One 9: e111780

50. Halpern KB, Caspi I, Lemze D, Levy M, Landen S, Elinav E, Ulitsky I, Itzkovitz S (2015) Nuclear retention of mRNA in mammalian tissues. Cell Rep 13: 2653-2662 


\section{The role of ethylene and transcriptome alterations in response to hypoxia stress in plants}

\section{Sylwia Górka ${ }^{\varpi}$, Dorota Olszewska, Dawid Kubiak, Janusz Niedojadło ${ }^{\natural}$}

Department of Cellular and Molecular Biology; Nicolaus Copernicus University in Torun

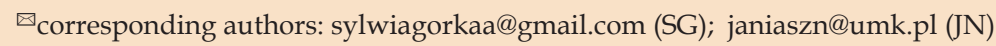

Key words: hypoxia, ERF - ethylen respose factor, transcriptome, Ribo-seq, nuclear retention of RNA

\section{SUMMARY}

Hypoxia in plants is a usually the result of heavy rainfall and the subsequent flooding. All current climate models indicate a notable increase in extreme weather over the coming years. Depending on the species and geographical location, plants have developed two distinct strategies for hypoxia stress adaptation: escape and quiescence. The escape strategy involves rapid growth of part of the shoot above the water level whereas the second strategy requires a significant reduction in the metabolic rate of the plant in order to survive until the negative environmental conditions pass. These processes are primarily regulated by ethylen in addition to the transcription factor, ERF (ethylen response factor), which enables the transcription of hypoxia response genes. These processes are primarily regulated by ethylen in addition to the transcription factors, ERFs (ethylen response factors), which enables the transcription of hypoxia response genes. Most ERF genes are constitutively transcribed independently of oxygen concentration. However, post-translational modification of the $\mathrm{N}$-terminus of ERFs leads to their degradation in plants growing under physiological conditions. During hypoxia there is an increase in the expression level of genes associated with carbon, nitrogen, glycolysis or anaerobic respiration. However, as shown by studies using ribosome profiling, in order to save energy, plants under hypoxic stress strongly inhibit the process of initiating translation. The regulation of gene expression under stress conditions is also influenced by the accumulation of poly(A) RNA in the cell nucleus and cytoplasmic stress granules. 